\title{
Incidence of Childhood Eosinophilic Esophagitis in Central Brazil: How Many Are We Missing?
}

\author{
Gonçalves LO, Lopes MMNR, Rezende ERMA, Segundo GRS \\ Pediatrics Department, Clinical Hospital of Universidade Federal de Uberlândia, Uberlândia, Brazil
}

J Investig Allergol Clin Immunol 2018; Vol. 28(4): 241-245

doi: 10.18176/jiaci.0241

\begin{abstract}
Background: Few studies have assessed the incidence of eosinophilic esophagitis (EoE) in childhood. Our study aimed to determine the incidence of EoE in pediatric patients undergoing upper gastrointestinal endoscopy (UGE), with analysis of epidemiological data including sex, age, symptoms, frequency of atopy, and endoscopic and histological findings.

Methods: We performed a retrospective, observational, analytical study of the medical records of patients aged 0 to 14 years who underwent UGE in a tertiary hospital from January 2004 to January 2014.

Results: A total of 4071 upper digestive endoscopies were performed in 2651 patients. Esophageal eosinophilia was found in 405 biopsy reports, and 127 patients had $\geq 15 /$ HPF. The clinical histories of 70 patients were analyzed. Sixty-three fulfilled the diagnostic criteria for EoE, 3 fulfilled the criteria for eosinophilic gastroenteritis, and 4 cases were secondary to caustic ingestion. The mean annual incidence was 2.48/100 000 individuals/year and the cumulative incidence over 10 years was 24.8/100 000. No statistical differences were found between responders to proton pump inhibitors and nonresponders for age, gender, atopic diseases, symptoms, and endoscopy findings. Conclusion: The incidence of EoE in the present study was similar to that reported in the literature. However, these data may be underestimated owing to difficulties accessing UGE. Increased knowledge of esophageal eosinophilic diseases in childhood requires associated improvements in health infrastructure.
\end{abstract}

Key words: Eosinophilic esophagitis. Proton pump inhibitor responsive esophageal eosinophilia. Atopic diseases. Childhood. Prevalence.

\section{Resumen}

Antecedentes: Pocos estudios han evaluado la incidencia de esofagitis eosinofílica (EoE) en la infancia. El objetivo del estudio es determinar la incidencia de EoE en pacientes pediátricos sometidos a endoscopia gastrointestinal alta (UGE), mediante un análisis de datos clínico epidemiológicos incluyendo sexo, edad, sintomatología, frecuencia de atopia con relación a los hallazgos endoscópicos e histológicos. Métodos: Estudio retrospectivo, observacional y analítico cuya fuente de datos eran las historias clínicas de pacientes de 0 a 14 años que se habían realizado una endoscopia digestiva alta en un hospital terciario, entre enero de 2004 y enero de 2014.

Resultados: Se realizaron un total de 4.071 endoscopias digestivas altas en 2.651 pacientes. Se encontró eosinofilia esofágica en 405 informes de biopsias, siendo 127 con 15 o más eosinófilos por campo de alta potencia, presentes en 70 pacientes diferentes. Sesenta y tres cumplieron los criterios de diagnóstico para la EoE, tres para la gastroenteritis eosinofílica y cuatro fueron tóxicas secundarias a ingestión cáustica. La incidencia media anual fue de 2,48/100 000 individuos / año y la incidencia acumulada durante diez años fue de $24,8 / 100000$. No se encontraron diferencias estadísticamente significativas entre los pacientes con respuesta a inhibidores de la bomba de protones (PPI) y los que no respondieron, con respecto a la edad, sexo, enfermedades atópicas, síntomas y hallazgos endoscópicos. Conclusión: La incidencia de EoE encontrada en el presente estudio fue similar a la descrita en la literatura, sin embargo, estos datos pudieran ser subestimaciones debido a las dificultades para acceder a UGE. El aumento del conocimiento sobre las enfermedades eosinofílicas esofágicas en la infancia requiere una mejora asociada en la infraestructura de los sistemas sanitarios.

Palabras clave: Esofagitis eosinofílica. Eosinofilia esofágica con respuesta a inhibidor de la bomba de protones. Enfermedades atópicas. Infancia. Prevalencia. 


\section{Introduction}

Eosinophilic esophagitis (EoE) is a chronic, immune/ antigen-mediated disease that is characterized clinically based on signs of esophageal dysfunction and histologically based on the presence of an inflammatory, predominantly eosinophilic, infiltrate $[1,2]$. Prior studies have identified an association between atopic diseases such as food allergy, allergic rhinitis, atopic dermatitis, asthma, and EoE [3]. The clinical symptoms differ with age; EoE should be considered in older children and adults who present with symptoms of esophageal dysfunction and/or fibrosis such as dysphagia, odynophagia, or food impaction. In infants and younger children, the symptoms often mimic those associated with gastroesophageal reflux disease (GERD) [1]. Since the interacting relationship between GERD and EoE might be bidirectional, they are not mutually exclusive disorders and may coexist in a single patient, albeit without interacting [2].

In 2011, the diagnostic criterion for EoE recommended by an expert panel was $\geq 15$ eosinophils/HPF in 1 or more fields of biopsy specimens (minimum 4 specimens) while the patient is receiving an appropriate dose of proton pump inhibitor (PPI). The eosinophils must be detected exclusively in the esophagus, and other diseases associated with EoE must be excluded [1]. Cumulative evidence since then has clearly demonstrated that PPI-responsive EoE (PPI-REE) and EoE are completely overlapping diseases in terms of symptoms, endoscopic and histologic findings, molecular signature, and gene signature. In addition, patients achieving clinical and histological remission with PPI therapy are considered part of the EoE continuum, rather than a separate entity [2]. Other endoscopic findings such as thickening and opacity of the mucosa, esophageal rings, and white exudates are common in EoE, although an endoscopically normal esophagus does not exclude the disease $[1,2,4,5]$. Histology reveals the esophageal tissue of patients with EoE to be characterized by esophageal barrier alterations such as basal layer cell hyperplasia, papillary elongation, dilation of the intercellular space, and presence of microabscesses and eosinophilic infiltrates $[1,2,5]$. Untreated EoE can result in significant impairment in quality of life, and, once diagnosed, esophageal inflammation should be managed through topical corticosteroid therapy and/or allergen identification and avoidance in order to relieve symptoms and prevent food impaction resulting from esophageal stricture formation [2].

Limited studies with various designs, including prospective and retrospective case registries, endoscopy series, and population-based studies show that the incidence and prevalence of EoE have increased [6]. The prevalence of EoE is associated with access to endoscopy. Difficulty accessing this procedure means that prevalence is often underestimated, since the diagnosis depends on histological confirmation [7]. The incidence and prevalence of eosinophilic esophageal diseases are not known in Brazil; previously published studies focused on isolated cases or case series [8,9]. Knowledge of the prevalence of a disease enables us to understand its impact on the population and to prepare the infrastructure necessary for control.

We performed a retrospective cohort study to determine the annual incidence of EoE in pediatric patients and the cumulative incidence over a 10 -year period. We analyzed demographic and clinical data, endoscopy reports, and biopsy results.

\section{Materials and Methods}

The Gastrointestinal Endoscopy unit at Clinical Hospital of Universidade Federal de Uberlandia (HC-UFU) is the only provider of upper gastrointestinal endoscopy (UGE) for a pediatric population from 30 cities that make up our reference macroregion (253 706 children aged 0 to 14 years). According to the census of the Brazilian Institute of Geography and Statistics, the number of persons in the region has remained stable for the last decade [10]. This estimation for the regional population was used to calculate prevalence.

We generated a retrospective cohort by analyzing data from the electronic records of 4071 UGE procedures in children at our hospital between January 2004 and January 2014. Direct patient identifiers were removed to create an anonymous dataset; the available data included the date of birth, date of UGE, diagnosis, and UGE code. According to the hospital electronic records, these 4071 endoscopies were performed on 2651 different patients. After analysis of the biopsies, all patient medical records that presented $\geq 15$ eosinophils/ HPF were analyzed, and data related to clinical features and UGE findings were added to the patient's datasheet. The diagnosis of EoE, PPI-REE, and other eosinophilic diseases was reviewed according to guidelines $[1,2,4]$. The research study was approved by the ethics committee of Universidade Federal de Uberlandia.

The $t$ test was used for the analysis of continuous variables and the Fisher exact test was used for the categorical variables. Statistical significance (2-tailed) was set at $P<.05$ using the program GraphPad Prism 5.0.

\section{Results}

The flowchart of our study cohort is shown in the Figure. A total of 4071 UGEs were performed in 2651 patients during the study period; of these, only 2158 (53\%) yielded esophageal biopsies, and esophageal eosinophilia was reported in 405, of whom $127 \mathrm{had} \geq 15$ eosinophils/HPF. Of these 127 patients, the clinical histories were analyzed in 70 cases, that is, $2.64 \%$ of the 2651 patients who underwent UGE (Figure). The diagnostic criteria for EoE were fulfilled in $63(2.38 \%)$, and those for eosinophilic gastroenteritis were fulfilled in $3(0.11 \%)$. A further 4 patients $(0.15 \%)$ in this group of 70 patients presented $\geq 15 / \mathrm{HPF}$ in the UGE after caustic ingestion; EoE improved in 2 cases after treatment with PPI, and a further 2 patients did not undergo subsequent UGE. An intriguing finding in patients with EoE was that of 9 patients with cerebral palsy.

Calculations were based on the total number of children aged 0 to 14 years living in the reference macroregion for our hospital, that is, 253 706. The mean incidence of EoE was 2.48 cases per 100000 individuals/year (Table 1). The 10year cumulative incidence of confirmed EoE was found to be 24.8 children per 100000 . In our cohort, 11 out of 63 patients 


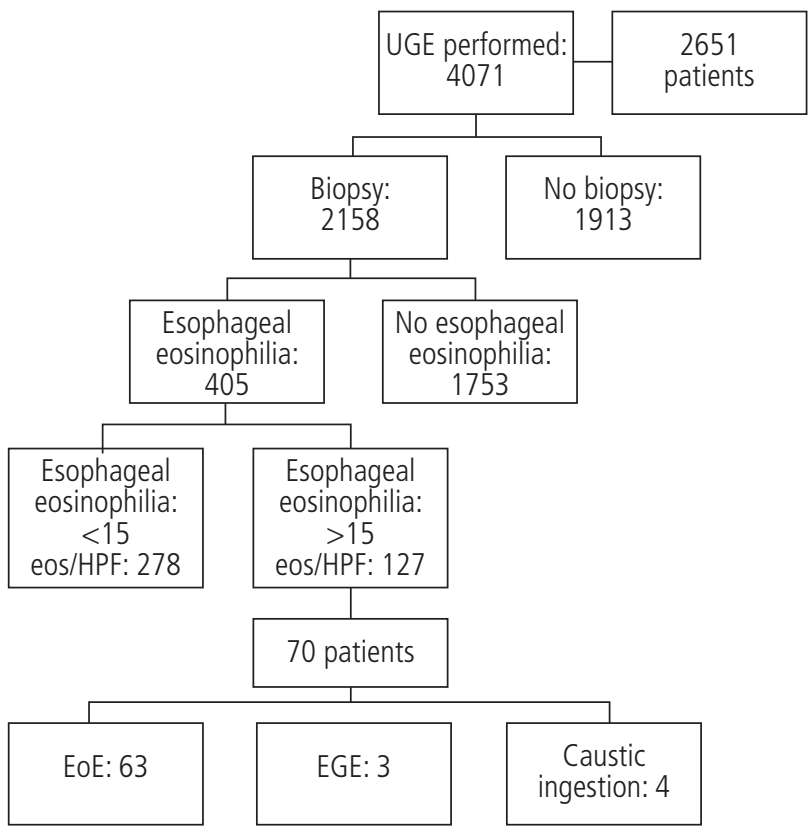

Figure. Study flowchart. UGE indicates upper gastrointestinal endoscopy; EoE, eosinophilic esophagitis; EGE, eosinophilic gastroenteritis.

$(17.46 \%)$ were found to have a histologic response to PPIs, while $31(49.21 \%)$ were considered nonresponders. A further $21(33.33 \%)$ did not have a follow-up UGE and cannot therefore be classified as PPI responders or nonresponders.

The comparison between the groups of confirmed PPI responders and nonresponders did not show significant differences regarding gender, age, the presence of atopic

Table 1. Incidence of Esophageal Eosinophilia Per Year and the Cumulative 10-Year Incidence of Eosinophilic Esophagitis in Children Aged 0-14 Years in the Reference Macroregion Served by Universidade Federal de Uberlandia, Brazil

\begin{tabular}{lcc}
\hline Year & $\begin{array}{c}\text { Esophageal } \\
\text { Eosinophilia, } \\
\text { No. of Cases }\end{array}$ & $\begin{array}{c}\text { Incidence } \\
\text { (per 100 000 } \\
\text { Inhabitants) }\end{array}$ \\
\hline 2004 & 2 & 0.78 \\
2005 & 3 & 1.19 \\
2006 & 5 & 1.96 \\
2007 & 9 & 3.54 \\
2008 & 6 & 2.36 \\
2009 & 9 & 3.54 \\
2010 & 7 & 2.76 \\
2011 & 8 & 3.15 \\
2012 & 7 & 2.76 \\
2013 & 7 & 2.76 \\
Mean (10 years) & 6.3 & 2.48 \\
Total (10 years) & 63 & 24.80 \\
\hline
\end{tabular}

diseases, or symptoms (Table 2). Although there are no statistical differences, only the nonresponder group included cases of food impaction. Vomiting was more frequent than dysphagia in the nonresponder group, and the opposite was seen in the responder group (Table 2).

Although endoscopic alterations were more frequent in the nonresponder group, where 28 cases were registered $(90.3 \%)$, there were no significant differences with respect to the responder group (Table 3 ). The same occurred when we compared the number of eosinophils between the groups (Table 1).

Eosinophilic gastroenteritis was diagnosed in only 3 patients, all male and with a history of food allergy in $2(66.6 \%)$. These findings were similar to those from the other groups (data not shown).

Table 2. Demographic and Clinical Characteristics of Patients With Eosinophilic Esophagitis Who Responded and Did Not Respond to Proton Pump Inhibitors

\begin{tabular}{lccc}
\hline & $\begin{array}{c}\text { Nonresponders } \\
\mathrm{n}=31(\%)\end{array}$ & $\begin{array}{c}\text { Responders } \\
\mathrm{n}=11(\%)\end{array}$ & $P$ Value \\
\hline Mean (SD) age, mo & $87.10(8.95)$ & $106.3(12.68)$ & $.2395^{\mathrm{a}}$ \\
Gender & $17(54.83)$ & $7(63.63)$ & $.7306^{\mathrm{b}}$ \\
$\quad$ Male & $14(45.16)$ & $4(36.37)$ & \\
Female & & & \\
Atopy & $9(29.03)$ & $2(18.18)$ & $.6959^{\mathrm{b}}$ \\
$\quad$ Asthma & $16(51.61)$ & $6(54.54)$ & $1.0000^{\mathrm{b}}$ \\
Rhinitis & $19(61.29)$ & $4(36.37)$ & $.1719^{\mathrm{b}}$ \\
Food allergy & $4(12.90)$ & $1(9.09)$ & $1.0000^{\mathrm{b}}$ \\
Atopic dermatitis & & & \\
Symptoms & $18(58.06)$ & $5(45.45)$ & $.5038^{\mathrm{b}}$ \\
Abdominal pain & $10(32.25)$ & $4(36.37)$ & $1.0000^{\mathrm{b}}$ \\
$\quad$ Vomiting episodes & $8(25.80)$ & $5(45.45)$ & $.2700^{\mathrm{b}}$ \\
Dysphagia & $6(19.35)$ & $0(0.00)$ & $.1724^{\mathrm{b}}$ \\
Impaction & & & \\
\hline at test. & & & \\
${ }^{\mathrm{b}}$ Fisher exact test. & &
\end{tabular}

Table 3. Endoscopic and Histological Characteristics of Patients Who Responded and Did Not Respond to Proton Pump Inhibitors

\begin{tabular}{lccc}
\hline & $\begin{array}{c}\text { Nonresponders } \\
\mathrm{n}=31(\%)\end{array}$ & $\begin{array}{c}\text { Responders } \\
\mathrm{n}=11(\%)\end{array}$ & $P$ Value \\
\hline $\begin{array}{l}\text { Endoscopic alterations } \\
\text { Thickening, No. (\%) }\end{array}$ & $10(32.25)$ & $3(23.07)$ & $.7223^{\mathrm{a}}$ \\
$\begin{array}{l}\text { Opacity, No. (\%) } \\
\text { Longitudinal }\end{array}$ & $15(48.38)$ & $5(38.46)$ & $.7416^{\mathrm{a}}$ \\
$\begin{array}{l}\text { furrows, No. (\%) } \\
\begin{array}{l}\text { White exudates, } \\
\text { No. (\%) }\end{array}\end{array}$ & $11(35.48)$ & $2(15.38)$ & $.2825^{\mathrm{a}}$ \\
$\begin{array}{l}\text { Rings, No. (\%) } \\
\text { Hyperemia, No. (\%) }\end{array}$ & $10(32.25)$ & $1(7.69)$ & $.1321^{\mathrm{a}}$ \\
$\begin{array}{l}\text { Mean (SD) } \\
\text { eosinophils/HPF }\end{array}$ & $41.45(5.25)$ & $3(23.07)$ & $1.0000^{\mathrm{a}}$ \\
\hline
\end{tabular}

${ }^{a}$ Fisher exact test.

${ }^{\mathrm{b}} t$ test.

HPF, High Power Field 


\section{Discussion}

The present study is the first to determine the incidence and cumulative incidence of pediatric EoE in Brazil and Latin America. A recent systematic review and meta-analysis to estimate incidence and prevalence rates of EoE showed that after analysis of 1334 references, only 13 population-based studies from North America, Europe, and Australia could be included, thus indicating high heterogeneity in the results [6]. The reported annual incidence ranged from 0.28 [11] to 19.6 [12] per 100000 inhabitants/year and an overall incidence rate estimate of 3.7 per 100000 inhabitants/year, considering that the studies were pooled [6]. The results also showed a slightly higher incidence in adults (7/100 000 persons/year) than in children $(5.1 / 100000)$ [6].

Only 6 pediatric studies were selected for the meta-analysis, with 5 from the USA and 1 from Denmark. An additional study was included after careful evaluation [6,13-18]. The annual incidence in children ranged from 0.7 [13] to 16.8 [14] per 100000 individuals/year (both studies conducted in the USA). Although the mean annual incidence of EoE found in our study (2.48/100 000 individuals/year) is lower than that observed in the final results of the recent meta-analysis (5.1/100 000), the value is within the range recorded for the participating studies and fairly similar to the annual incidence found in a large nationwide database study (2.9/100 000) [18]. The lower incidence before 2007 also was seen in a previous systematic review and is related to the absence of systematic guidelines on diagnosis of EoE [6].

A study performed in a pediatric population who underwent UGE in Saudi Arabia found a frequency of EoE of $0.85 \%$ after the evaluation of 2127 endoscopies [19]. In our study, 31 of the 2651 patients who underwent UGE had confirmed EoE, that is, a slightly greater frequency $(1.17 \%)$.

The clinical and endoscopic characteristics of EoE in PPI responders and nonresponders in our study are similar to those reported elsewhere [20-24]. This reinforces the recent consensus that considered EoE and PPI-REE as different diseases on the same spectrum that should be recognized as EoE [2,23-27]. Dranove et al [26] evaluated children with EoE to identify predictors of the response to PPI but were unable to find any. In the univariate analysis, patients with abnormal $\mathrm{pH}$ and an eosinophil count of between 15 and 20 eos/HPF seemed to respond better to PPIs.

In contrast to adults, who experience dysphagia and impaction, children with EoE often have nonspecific symptoms, thereby delaying diagnosis in this age range $[2,4,5]$. Complaints such as difficulties when eating, vomiting episodes, and abdominal pain are the most frequent, with these symptoms affecting more than half of all patients. The frequency of the symptoms found in this study is similar to that reported in North America [15].

Although a normal UGE examination does not exclude the disease, macroscopic alterations frequently observed during the endoscopy procedure include white plaques, mucosal edema, longitudinal furrows, and esophageal rings, as seen in the present study $[1,2,4,5]$. Again, no statistical differences were found between PPI responders and nonresponders.

The high prevalence of EoE in patients with cerebral palsy is noteworthy. Gastrointestinal diseases are common in children with psychomotor impairment, and although reflux disease is more common, we should suspect EoE in patients who do not respond to conventional GERD treatment [28].

The limitations of the present study include the retrospective assessment of clinical records, the lack of a structured study protocol when patients were assessed, and the reduced accuracy of the data obtained from the retrospective assessment, especially the esophageal features of EoE observed in the UGE. The number of patients with EoE may not have been satisfactory, even though we enrolled all patients with EoE treated at our institution over 10 years. In addition, the biopsy reports were obtained from only $53 \%$ of UGE procedures. Also important is the difficulty accessing UGE in our region, especially in children. The long waiting lists discourage patients from attending, thus preventing a diagnosis of EoE from being made.

In conclusion, the incidence of EoE in the present study was similar to that described in the literature. These data may be underestimated due difficulties accessing UGE and the number of UGEs performed without biopsies. Larger multicenter prospective studies will be necessary to obtain more accurate results. Finally, increased knowledge of EoE can only be based on improvements in health care infrastructure, which will in turn provide adequate diagnosis, treatment, and follow-up of patients.

\section{Acknowledgments}

We would like to thank the physicians of the Sector of Endoscopy and Pathology of HC-UFU for their contribution to the examinations. We are also grateful to the Statistics and Information Sector and Archive and Research Sector of the Hospital de Clínicas da Universidade Federal de Uberlândia for providing support for this research study.

\section{Funding}

The authors declare that no funding was received for the present study.

\section{Conflicts of Interest}

The authors declare that they have no conflicts of interest.

\section{References}

1. Liacouras CA, Furuta GT, Hirano I, Atkins D, Attwood SE, Bonis PA, et al. Eosinophilic esophagitis: updated consensus recommendations for children and adults. J Allergy Clin Immunol. 2011;128:3-20.

2. Lucendo AJ, Molina-Infante J, Arias Á, von Arnim U, Bredenoord AJ, Bussmann C, et al. Guidelines on eosinophilic esophagitis: evidence-based statements and recommendations for diagnosis and management in children and adults. United European Gastroenterol J. 2017:5:335-58.

3. González-Cervera J, Arias Á, Redondo-González 0, CanoMollinedo MM, Terreehorst I, Lucendo AJ. Association between atopic manifestations and eosinophilic esophagitis: A systematic review and meta-analysis. Ann Allergy Asthma Immunol. 2017;118:582-90. 
4. Furuta GT, Liacouras CA, Collins MH, Gupta SK, Justinich C, Putnam PE, et al. Eosinophilic esophagitis in children and adults: a systematic review and consensus recommendations for diagnosis and treatment. Gastroenterology. 2007;133:1342-63.

5. González-Cervera J, Lucendo AJ. Eosinophilic Esophagitis: An Evidence-Based Approach to Therapy. J Investig Allergol Clin Immunol. 2016;26:8-18.

6. Arias Á, Pérez-Martínez I, Tenías JM, Lucendo AJ. Systematic review with meta-analysis: the incidence and prevalence of eosinophilic oesophagitis in children and adults in populationbased studies. Aliment Pharmacol Ther. 2016;43:3-15.

7. Mandeville KL, Krabshuis J, Ladep NG, Mulder CJ, Quigley EM, Khan SA. Gastroenterology in developing countries: issues and advances. World J Gastroenterol. 2009;15:2839-54.

8. Rezende ER, Barros CP, Ynoue LH, Santos AT, Pinto RM, Segundo GR. Clinical characteristics and sensitivity to food and inhalants among children with eosinophilic esophagitis. BMC Res Notes. 2014;7:47.

9. Ferreira CT, Vieira MC, Vieira SM, Silva GS, Yamamoto DR, Silveira TR. Eosinophilic esophagitis in 29 pediatric patients. Arq Gastroenterol. 2008;45:141-6.

10. Brazil, IBGE. Demographic Census, 2010. Available at: http:// cod.ibge.gov.br/HGRC. Accessed December 29, 2016.

11. vanRhijn BD, Verheij J, Smout AJ, Bredenoord AJ. Rapidly increasing incidence of eosinophilic esophagitis in a large cohort. Neurogastroenterol Motil. 2013;25:47-52.

12. Dellon ES, Jensen ET, Martin CF, Shaheen NJ, Kappelman MD. Prevalence of Eosinophlic Esophagitis in the United States. Clin Gastroenterol Hepatol. 2014;12:589-96.

13. Gill R, Durst P, Rewalt M, Elitsur Y. Eosinophilic esophagitis disease in children from West Virginia: a review of the last decade (1995-2004). Am J Gastroenterol. 2007;102:2281-5.

14. Dalby K, Nielsen RG, Kruse-Andersen S, Fenger C, BindslevJensen $C$, Ljungberg $S$, et al. Eosinophilic esophagitis in infants and children in the region of southern Denmark: a prospective study of prevalence and clinical presentation. J Pediatr Gastroenterol Nutr. 2010;51:280-2.

15. Dellon ES, Jensen ET, Martin CF, Shaheen NJ, Kappelman MD. Prevalence of eosinophilic esophagitis in the United States. Clin Gastroenterol Hepatol. 2014;12:589-96.

16. Noel RJ, Putnam PE, Rothenberg ME. Eosinophilic esophagitis. N Engl J Med. 2004;351:940-1.

17. Ally MR, Maydonovitch CL, Betteridge JD, Veerappan GR, Moawad FJ. Prevalence of eosinophilic esophagitis in a United States military health-care population. Dis Esophagus. 2015;28:505-11.

18. Prakash R, Maradey C, Fass R. Eosinophilic esophagitis is much less common than previously thought: a large nationwide database study. Am J Gastroenterol. 2013; 108(Suppl.1):S33.

19. Saadah OI,AburizizaAJ,Abu Shakra RI. Eosinophilic esophagitis in children from Western saudi arabia: relative frequency, clinical, pathological, endoscopic, and immunological study. Gastroenterol Res Pract. 2012;328253.

20. Fujiwara Y, Sugawa T, Tanaka F, Tatsuwaki H, Okuyama M, Hayakawa $T$, et al. A multicenter study on the prevalence of eosinophilic esophagitis and PPI-responsive esophageal eosinophilic infiltration. Intern Med. 2012;51:3235-9.

21. Molina-Infante J, Ferrando-Lamana L, Ripoll C, HernandezAlonso M, Mateos JM, Fernandez-Bermejo M, et al. Esophageal eosinophilic infiltration responds to proton pump inhibition in most adults. Clin Gastroenterol Hepatol. 2011;9:110-7.

22. Atkins D, Furuta GT, Liacouras CA, Spergel JM. Eosinophilic esophagitis phenotypes: Ready for prime time? Pediatr Allergy Immunol. 2017:28:312-9.

23. Moawad FJ, Schoepfer AM, Safroneeva E, Ally MR, Chen YJ, Maydonovitch $\mathrm{CL}$, et al. Eosinophilic oesophagitis and proton pump inhibitor-responsive oesophageal eosinophilia have similar clinical, endoscopic and histological findings. Aliment Pharmacol Ther. 2014;39:603-8.

24. Jiao D, Ishimura N, Maruyama R, Ishikawa N, Nagase M, Oshima $N$, et al. Similarities and differences among eosinophilic esophagitis, proton-pump inhibitor-responsive esophageal eosinophilia, and reflux esophagitis: comparisons of clinical, endoscopic, and histopathological findings in Japanese patients. J Gastroenterol. 2017;52:203-10.

25. Dellon ES, Speck O, Woodward K, Gebhart JH, Madanick RD, Levinson $\mathrm{S}$, et al. Clinical and endoscopic characteristics do not reliably differentiate PPI-responsive esophageal eosinophilia and eosinophilic esophagitis in patients undergoing upper endoscopy: a prospective cohort study. Am J Gastroenterol. 2013;108:1854-60.

26. Dranove JE, Horn DS, Davis MA, Kernek KM, Gupta SK. Predictors of response to proton pump inhibitor therapy among children with significant esophageal eosinophilia. J Pediatr. 2009;154:96-100.

27. Dellon ES, Speck O, Woodward K, Covey S, Rusin S, Gebhart $\mathrm{JH}$, et al. Markers of eosinophilic inflammation for diagnosis of eosinophilic esophagitis and proton pump inhibitorresponsive esophageal eosinophilia: a prospective study. Clin Gastroenterol Hepatol. 2014;12:2015-22.

28. de Nápolis ACR, Alves FA, Rezende ERM, Segundo GRS Esophageal eosinophilia in patients with cerebral palsy. Einstein. 2015;13:232-7.

Manuscript received October 21, 2017; accepted for
publication February 16, 2018.

- Gesmar Rodrigues Silva Segundo

Pediatrics Department, Universidade Federal

de Uberlândia

Av. Pará, 1720, Bloco 2H

Uberlândia, MG, Brasil. CEP 38400-902

E-mail: gesmar@famed.ufu.br 